\title{
INTEGRATING GIS AND SPATIAL ANALYTICAL TECHNIQUES IN AN ANALYSIS OF ROAD TRAFFIC ACCIDENTS IN SERBIA
}

Liljana Çela ${ }^{1}$, Shino Shiode ${ }^{2}$, Krsto Lipovac ${ }^{3}$

${ }^{1}$ South East Europe Transport Observatory, Omladinskih Brigada 1, Belgrade, Serbia

${ }^{2}$ Department of Geography, Environment \& Development Studies, Birkbeck, University of London, Malet Street, London WC1E 7HX

${ }^{3}$ The Faculty of Criminal Justice and Police Academy, 11080 Zemun, Cara Dusana 196, Belgrade, Serbia

Received 26 September 2012; accepted 7 December 2012

Abstract: Road safety issue is drawing major attention of local Serbian authorities who seeks the reduction of the volume of Road Traffic Accidents. The study starts with a summative review of the problem with a focus on the situation in the European Union member countries and the Western Balkan (WB) countries: Albania, Bosnia and Herzegovina, Croatia, Montenegro, the former Yugoslav Republic of Macedonia, Kosovo and Serbia. It then interprets traffic accident data using network K-function and Network Kernel Density Estimation. Unlike the conventional planar methods, the network methods analyze the spatial patterns of accident locations within the network space and are therefore not affected by the configuration of the street network or its distance. The Network K-function helped authors to investigate the presence of clusters, whereas the Network Kernel Density method helped identify the actual cluster locations. Multiple linear regression analysis was also used to find the most significant variables related to the road conditions, time and the main cause which have likely contributed to high rates of accidents. The empirical analysis was carried out using traffic data from the City of Belgrade. Implications for further research were discussed, suggesting that the findings can be used for more in-depth studies aimed at identifying the most significant cause of road accidents in any given area and that they could be extended and applied in other countries of the region.

Keywords: GIS, network analysis, road traffic accidents.

\section{Introduction}

The rise in the number of fatalities has been drawing worldwide attention to road safety issues. Prevention of Road Traffic Accidents (RTA) requires developing good methods for identifying, analyzing and treating exposed areas. In 1990, RTAs were ranked as the $9^{\text {th }}$ most significant cause of death annually in the world according to the statistics of the World Health Organization (WHO). In fact, WHO estimates that RTAs will become the fifth leading cause of death by 2030 and the third leading contributor in the industrialized world. These figures and facts make RTAs one of the major concerns of public health and welfare, since they are seen as a global 'epidemic'.

Industrial development after World War II has brought about the need for increasing motorization in the developed countries. Jacobs et al. (2000) refer to the dichotomy of developing vs. developed countries, high vs. low income, and high motorization vs. low

${ }^{1}$ Corresponding author: 1cela@seetoint.org 
motorization. Their study shows that even though the developed countries are highly motorized, $70 \%$ of RTAs occur in developing countries. Similarly, Global Status Report (2009) on road safety, which is based on data from 174 countries in the world, reveals that over $90 \%$ of RTAs occur in middle- or lowincome countries, which account for only $48 \%$ of the world's vehicle ownership. The aim of this study is to show the trend in RTAs and to increase the awareness of RTA issues in developing countries, particularly in $\mathrm{WB}$, by carrying out a statistical and GIS visual analysis of recent RTA data.

\section{Background}

\subsection{Road Accidents in Developed Countries (Europe)}

On 30 November 1993, the Council of Europe decided to create a community database on RTAs (Council Decision 93/704/EC, 1993).
Community database on Accidents on the Roads in Europe (CARE) comprises data on fatalities and injuries with the main purpose of identifying and quantifying the road safety issues, and measuring the efficiency of road safety measures. In 2010, the number of fatalities was down to almost half of the figure from 2000 (Fig. 1), making the EU accomplish one of its most ambitious objectives of the previous decade. The graph clearly shows the progress that has been made over the last 10 years, although a lot of work is yet to be done. Government, international agencies and organizations of civil societies from over 100 countries are launching the Decade of Action for Road Safety 2011-2020, which intends to save 5 million lives.

\subsection{Road Safety in the Western Balkans}

Countries of WB as developing countries are trying to comply with the rules and regulations of the EU, including those in the field of transport.

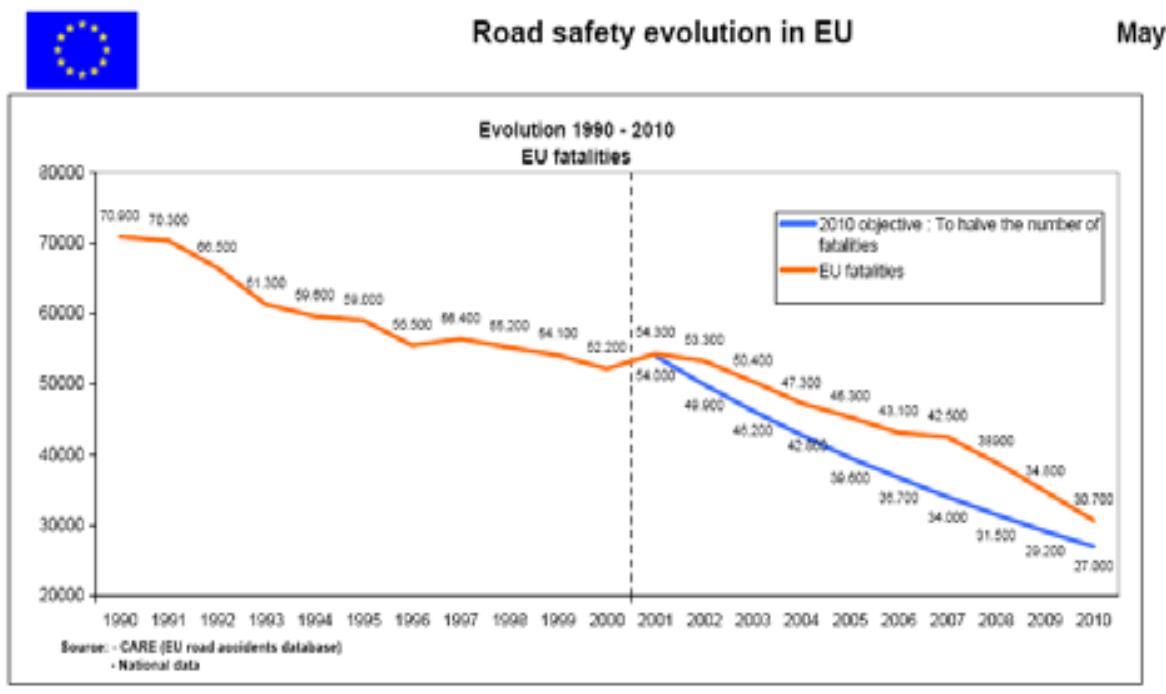

Fig. 1.

Change in the Volume of EU-Wide Road Accident Fatalities (1991-2010) 
In $\mathrm{WB}$, road safety falls under the responsibility of the Ministry of Interior, and the police are responsible for collecting information on the spot. It is part of the national integration strategy to improve road safety and is carried out jointly by the Ministry of Interior, the Ministry of Transport, and the Ministry of Health. The road safety situation in $\mathrm{WB}$, including major indicators, trends and swat analysis, is presented in the Multi Annual Plan (MAP) of South East Europe Transport Observatory (SEETO, 2011) on a yearly basis. It collects data through questionnaires in all countries.

The figures in Table 1 show a decrease in road fatalities in Bosnia and Herzegovina, Croatia and Serbia, which is a result of tougher law enforcement, better institutional framework, and identification of the road safety problems. Even though some improvements were made, the overall risk indicators remain above the EU average, not showing a decrease in their trend. As downward trends were only observed last year, they need to be confirmed in the upcoming years. The current situation is that data collected on the spot exist in the form of Excel spreadsheets on which statistical analysis is performed, which in turn is used by road safety engineers for further decision making. The location of the accident is defined per kilometer, even though each country uses mileage for planning and managing their respective road network.

There is an idea that investing in a shared database and GIS technology will provide a better solution to the road safety issues. However, this is still in the future. Currently, in each country, the respective public institutions individually publish statistical data regarding road safety issues at the national level.

\subsection{Road Traffic Accidents in Serbia}

Serbia lies in the North-East of the Western Balkans and has the largest population in the

Table 1

Population, Total Number of Accidents, Injuries and Fatalities in WB (2008-2009)

\begin{tabular}{|c|c|c|c|c|c|c|c|c|c|c|}
\hline \multirow{2}{*}{ Participant } & \multicolumn{2}{|c|}{$\begin{array}{c}\text { Population } \\
\text { (thousands) }\end{array}$} & \multicolumn{2}{|c|}{$\begin{array}{c}\text { Number of } \\
\text { Vehicles } \\
\text { thousands) }\end{array}$} & \multicolumn{2}{|c|}{$\begin{array}{c}\text { Number of } \\
\text { Accidents }\end{array}$} & \multicolumn{2}{|c|}{ Fatalities } & \multicolumn{2}{|c|}{ Injured } \\
\cline { 2 - 12 } & $\mathbf{2 0 0 8}$ & $\mathbf{2 0 0 9}$ & $\mathbf{2 0 0 8}$ & $\mathbf{2 0 0 9}$ & $\mathbf{2 0 0 8}$ & $\mathbf{2 0 0 9}$ & $\mathbf{2 0 0 8}$ & $\mathbf{2 0 0 9}$ & $\mathbf{2 0 0 8}$ & $\mathbf{2 0 0 9}$ \\
\hline Albania & 3,170 & 3,186 & 378 & 400 & 1,208 & 1,465 & 303 & 378 & 936 & 1,138 \\
\hline $\begin{array}{c}\text { Bosnia and } \\
\text { Herzegovina }\end{array}$ & 4,346 & 4,346 & 882 & 905 & 40,859 & 40,237 & 434 & 382 & 11,884 & 11,052 \\
\hline Croatia & 4,436 & 4,436 & 2,021 & 2,021 & 53,496 & 50,388 & 664 & 548 & 22,395 & 21,923 \\
\hline the fYRM & 2,023 & 2,067 & 279 & 320 & 16,106 & 14,941 & 162 & 160 & 6,724 & 6,891 \\
\hline Montenegro & 625 & 625 & 199 & 199 & 10,170 & 10,112 & 112 & 100 & 2,473 & 2,478 \\
\hline Serbia & 7,350 & 7,335 & 1,751 & 1,822 & 67,708 & 64,897 & 897 & 808 & 22,275 & 21,512 \\
\hline $\begin{array}{c}\text { Kosovo } \\
\text { (under } \\
\text { UNSCR }\end{array}$ & 2,350 & 2,350 & 355 & 400 & 11,313 & 13,346 & 117 & 152 & 6,247 & 7,984 \\
1244/99) & & & & & & & & & & \\
\hline Total & $\mathbf{2 4 , 3 0 0}$ & $\mathbf{2 4 , 3 4 6}$ & $\mathbf{5 , 8 5 6}$ & $\mathbf{6 , 0 6 7}$ & $\mathbf{2 0 0 , 8 6 0}$ & $\mathbf{1 9 7 , 0 1 6}$ & $\mathbf{2 , 6 8 9}$ & $\mathbf{2 , 5 2 8}$ & $\mathbf{7 2 , 9 3 4}$ & $\mathbf{7 2 , 9 7 8}$ \\
\hline
\end{tabular}

Source: SEETO MAP 2011 
region, at 7,335,000. As such, it is expected to have a higher number of motor vehicles, and consequently a higher number of traffic accidents as well. The data collected by SEETO confirms this tendency where Serbia comes first in WB during the period of 2004-2009, with the exception of 2003 when Croatia $(92,102$ cases $)$ had the highest number of RTAs. This is despite that, road safety is regarded as a high priority issue and is managed better than in the other countries of the region. Identifying patterns of road accidents in the national road network of Serbia and localizing the exposed places via GIS analysis, will help the policy makers, and this study aims to do precisely that by investigating the types of factors that attract road accidents in Belgrade.

\section{Study Area and Road Traffic Accident Data}

Only accidents which happened on the major road network of Serbia were considered in this study, excluding accidents which happened in the rural zones. Attribute fields provide information about the time (hour, day, month) the accident occurred, road characteristics, state of roads, road surface and main cause. The location of the accident is provided by attribute fields that define at which kilometer/meter of the road section the event occurred (e.g. the accident occurred at $500 \mathrm{~km}$ and $675 \mathrm{~m}$ on the M-1 road). Since we opted for a micro-scale research, we only used the data from within the boundaries of the municipalities of the capital city of Serbia, Belgrade. Also, for the features of the road network, which are given in sections associated with attributes such as start node, end node, and length, no data cleaning was done, and some additional fields such as Start Kilometer and End Kilometer were added instead.
The RTA data provided by Criminology Police Academy (CPA) comprise about 8,045 records for 2007 and have detailed information on the attributes collected. Some of the attributes, such as the police station that collected the data, persons who were guilty, whether traffic was stopped and how long it was stopped for, and damaged material, were deleted as they were not part of the relevant variables in this study. Also, accidents that happened in the rural and the suburban areas were not taken into account as the aim of this paper is to consider RTA events only on major roads. Accident Type is one of the attribute fields and is classified as 1. Fatal, 2. With serious injuries, and 3. With minor injuries or just material damage. After eliminating cases with an incomplete record, the sample size for this study became 2527 cases. A link was created between feature shaped file of the major roads and the respective Road ID section including the table which provides Annual Average Daily Traffic (AADT) attribute. No data cleaning was done concerning other indicators.

There is a significant number of RTAs that are not reported to the police. The studies of hospital and medical data are a case of under-reporting which is typical of lowincome countries (Aeron-Thomas, 2000). As under-reporting tends to happen in the case of serious injuries, definition of death or fatality cases becomes somewhat unclear. Some countries define it as "death on the spot" while others adopt the recommendation standard of "dead within 30 days". The field of accident type is the one that is affected by the above-mentioned reasons which can result in a greater number of RTAs than there really are. Also, using an approximation calculation instead of GPS devices creates uncertainty with respect to the location of an RTA, which is recorded at the scale of kilometer units.

\section{ijtte 4}




\section{Analysis of Traffic Accidents in Serbia}

\subsection{Methodology}

\subsubsection{Investigating the Relationship between Accidents and Causal Factors}

A number of analyses have been undertaken to see possible relationships between accident rates and other attributes (Dai, 2012). As road safety issues are complex, the method of multiple regression analysis, which tests the significance of multiple independent variables, is seen as the most efficient. Accidents as a complex problem are usually a product of the severity and combination of several causal factors each of which plays a role in the event that followed. In this study, we examined the relationship between the dependent variable 'accident rates' and other independent variables such as 'state of the road', 'road surface', 'road characteristics', 'main cause' and 'hour' or time of the day when the accident happened. The content of variables includes:

- Hour - which is the time when the accident happened and takes values from 1 to 24;

- Road Characteristics - which comprise information about the road design, i.e. whether the road is straight, curved, saddle or has junctions; it takes a dummy variable with values ranging from 1 to 15 ;

- State of the Road - which comprises values about the state of the road at the time of the accident. Values refer to categories dealing with whether the road is dry, wet, glazy or snow-covered;

- $\quad$ Surface Characteristics - which describes the surface material of the road and is categorized into asphalt, concrete, paved or unpaved;

- Main Cause - which is an explanation of the main cause of the accident. Overall, there are 110 causes.
All of the above variables are categorical with more than two levels and including them in the multiple regression analysis as independent variables would mean they need to be recoded in a number of dummy variables. Before dummy coding, some of the categories used for the independent variables were aggregated and collapsed together on the basis of their similarity: e.g. State of the Road values of "DRY-CLEAN", "DRY-COAT OF DUST and SAND, ETC." were grouped as DRY and was given the value of 1 . The same process was undertaken for all independent variables whereas 110 values of the main causes were grouped in 4 level categories:

- Alcohol/Drugs;

- Equipment Failure/Road Design;

- Not Obeying the Rules;

- Speed.

As regards the 'Hour' variable, it can be grouped into four categories relating to the daytime, as follows:
1. Morning
4-10 $\quad(>=4$ and $<10)$
2. Day 10-16 $(>=10$ and $<16)$
3. Afternoon $16-22 \quad(>=16$ and $<22)$
4. Night
$22-4$
$(>=22$ and $<4)$

All variables were dummy-coded after they were grouped into their respective categories.

The general rule is that a categorical variable with $\mathrm{k}$ levels can be transformed into $\mathrm{k}-1$ variables, and the last reference variable is the observation of all 0 values. In this case, the dummy variable was coded with two levels, 0 and 1 . Thus, independent variables that were to be included in the multiple regression formula were all dummies defined as in Fig. 2. 


dummy Road State variables
\begin{tabular}{|c|c|c|c|c|}
\hline Group SR & diS1 & dRS2 & dRS3 \\
\hline ORY & 2 & 0 & 0 \\
WLT & 0 & 1 & 0 \\
GLAZE & 0 & 0 & 0 \\
SNOW & 0 & 0 & 0
\end{tabular}

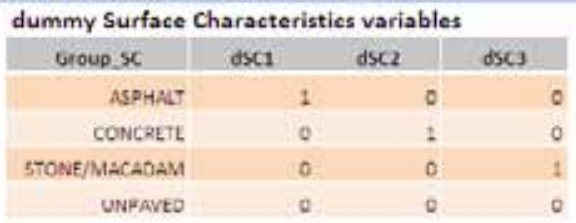

\begin{tabular}{|c|c|c|c|}
\begin{tabular}{|} 
dummy Hour variables \\
Group HOUH
\end{tabular} dH1 & dH2 & dHS \\
\hline $4-10$ & 1 & 0 & 0 \\
\hline $10-15$ & 0 & 1 & 0 \\
\hline $16-22$ & 0 & 0 & 1 \\
\hline $22-4$ & 0 & 0 & 0 \\
\hline
\end{tabular}

\begin{tabular}{|c|c|c|c|}
\hline Group_sc & dect & dHCZ & arcs \\
\hline ITHAIGTT & 1 & 0 & 0 \\
\hline CURVE/SAODIF & 0 & 1 & 0 \\
\hline JUNCTION & 0 & 0. & 2 \\
\hline LEVL CROSSING & Q & 0 & 0 \\
\hline
\end{tabular}

\begin{tabular}{|c|c|c|c|}
\hline Graup HOUA & dMC: & dMec 2 & dimc3 \\
\hline ALCOHOL/DRUGS & 1 & 0 & 0 \\
\hline NOT OBEVING THE RULES & 0 & t & 0 \\
\hline SPEED & 0 & 0 & 1 \\
\hline EQ FALUAR/ MOAD DESICN. & 0 & 0 & 0 \\
\hline
\end{tabular}

Fig. 2.

Dummy Variables Defined on the basis of the Hour, Road State, Surface Characteristics, Road Characteristics and the Main Cause Variables

As dummy variables can be used in the same way as the other variables, the predicted value $Y$ for calculating the dependent variable with multiple linear regression method can be written as Eq. (1):

$\mathrm{y}=\mathrm{B}_{0}+\mathrm{B}_{1} \mathrm{dH} 1+\mathrm{B}_{2} \mathrm{dH} 2+\mathrm{B}_{3} \mathrm{dH} 3+\mathrm{B}_{4} \mathrm{dRC} 1+\mathrm{B}_{5} \mathrm{dRC} 2+\mathrm{B}_{6} \mathrm{dRC} 3+\mathrm{B}_{7} \mathrm{dRS} 1+\mathrm{B}_{8} \mathrm{dRS} 2+$ $\mathrm{B}_{9} \mathrm{dRS} 3+\mathrm{B}_{10} \mathrm{dSC} 1+\mathrm{B}_{11} \mathrm{dSC} 2+\mathrm{B}_{12} \mathrm{dSC} 3+\mathrm{B}_{13} \mathrm{dMC} 1+\mathrm{B}_{14} \mathrm{dMC} 2+\mathrm{B}_{15} \mathrm{dMC} 3$

Accident rate value is defined as Eq. (2):

Accident rate for accident location $i=(\#$ accidents within a fixed distance $d$ from $i) /(\operatorname{AADT}$ for $i)$ (2)

where '\# accidents within a fixed distance $d$ from $i$ ' is calculated in ArcGIS by using the 'Point Density' tool. In this study, a smaller study area was chosen, covering only the municipalities of the capital city of Serbia, Belgrade, for the benefit of better performance and visualization. The radius used for searching the neighboring points $d=1000 \mathrm{~m}$ was chosen according to the content of data and the way AADT was measured.

\section{jitte 6}




\subsubsection{Identifying Cluster Patterns}

One of the popular methods for analyzing spatial patterns of incident data consisting of the locations of the event is Replay's $\mathrm{K}$ function. Event locations are usually available in planar (two-dimensional space) although there are cases when they are recorded in 3D space or along a line. Even though Ripley's $\mathrm{K}$ is one of the most effective methods for analyzing cluster patterns, it is based in a continuous planar space with Euclidian distance. Yamada and Thill (2002) used two types of $\mathrm{K}$ function, planar and network, and analyzed road traffic accidents in a road network in Buffalo, New York State.
It turned out that using planar method in a network could be misleading when it comes to outputs especially in the case of a constrained transport network, including traffic accidents. Therefore, when the events are located on network links, use of the network K-function method is recommended. This means that the distance between points would be measured by the shortest path on the network, as formulated by Okabe et al. (1995), in contrast with the planar method, which measures it in straight-line distance. Assuming that $r$ is the network radius and there are $n$ number of events $P=p_{1}, \ldots, p_{n}$ with the event density $\lambda$, the formula used for the calculation of the K-function is as follows (Eq. (3)):

$\mathrm{K}(\mathrm{r})=1 / \lambda \mathrm{E}$ (the number of points $P$ within network distance $r$ of a point $p_{i}$ of $P$ )

An extension of the Kernel density estimation method, applied to point distribution on a plane, is the Network Kernel Method that calculates the density in a linear unit (Okabe et al., 2009) which estimates the density points on a network based on formula (Eq. (4)):

$$
\lambda_{r}(s)=\sum_{\mathrm{i}=1}^{n} \frac{1}{r^{2}} k\left(\frac{d_{\mathrm{is}}}{r}\right)
$$

where $\lambda(s)$ is the density at location $s ; r$ is the bandwidth; and $k$ is the weight of point $i$ at distance $d_{i s}$ at location $s$.

Related to the above-mentioned points, the Network K function was used in this study to identify whether or not there was a tendency towards clustering in the entire accident distribution. In addition to confirming the patterns of the volume of accidents through network K, the Network Kernel function was applied to see where the concentrations were actually formed.

\subsection{Analysis and Results}

\subsubsection{Density Distribution of Accidents in Serbia}

$4,761.7 \mathrm{~km}$ of major road network length is laid in an 88,361 square kilometer area and the RTA locations are found across most of the network sections. In Fig. 38056 accidents that happened in the year 2007 in the Republic of Serbia are shown. As it can be seen, cluster patterns are present but it is hard to define where they are mostly located.

In order to get a better view of the issues and to alleviate issues arising from handling a large number of records, we chose the City of Belgrade for the study area which, as a capital city saw a high concentration of vehicle traffic with as many as 1,213,000 inhabitants registered as of 2009. The most congested section roads are sections of highway M-1 (Fig. 4), especially those within the New Belgrade municipality where AADT varies from 100,000 to 148,000 vehicles per year. 


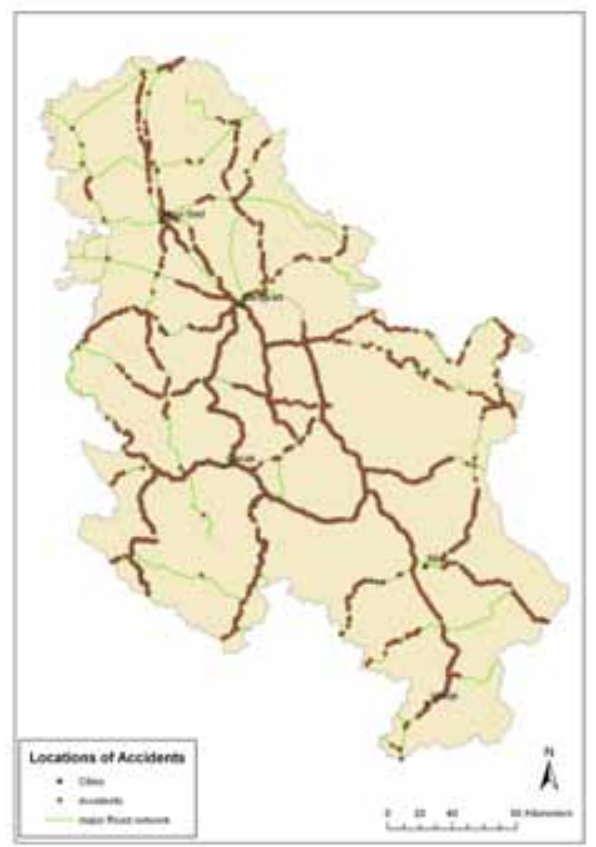

Fig. 3.

Locations of Road Traffic Accidents in the Major Road Network of Serbia (2007)

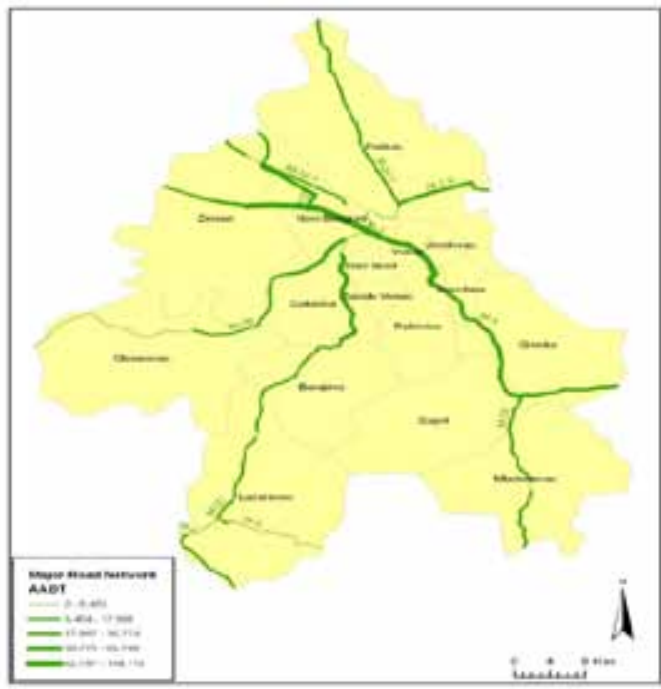

Fig. 4.

Annual Average Daily Traffic in the City of Belgrade (2007)

jitte 8 


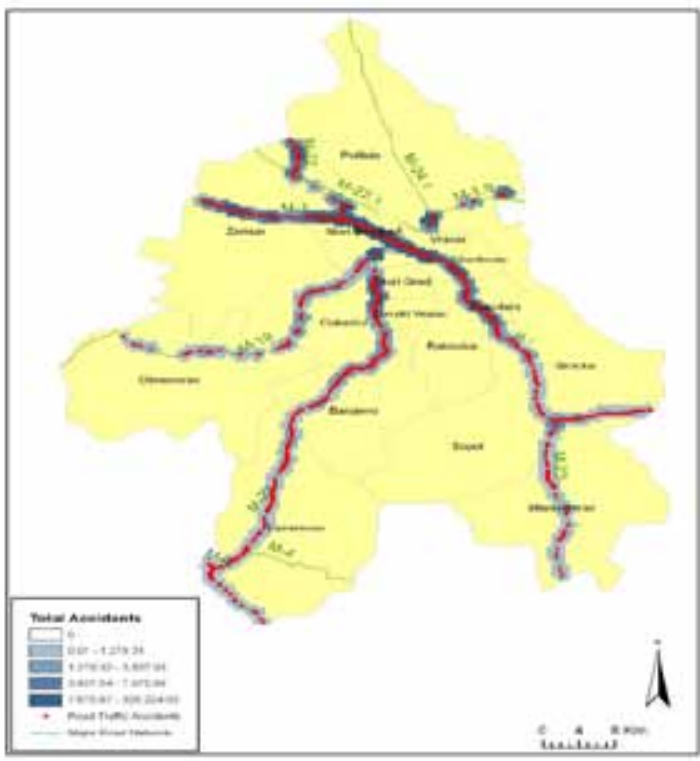

Fig. 5.

Density Map of Road Traffic Accidents in the City of Belgrade

\section{Observed and expected $\mathrm{K}$ function curves}

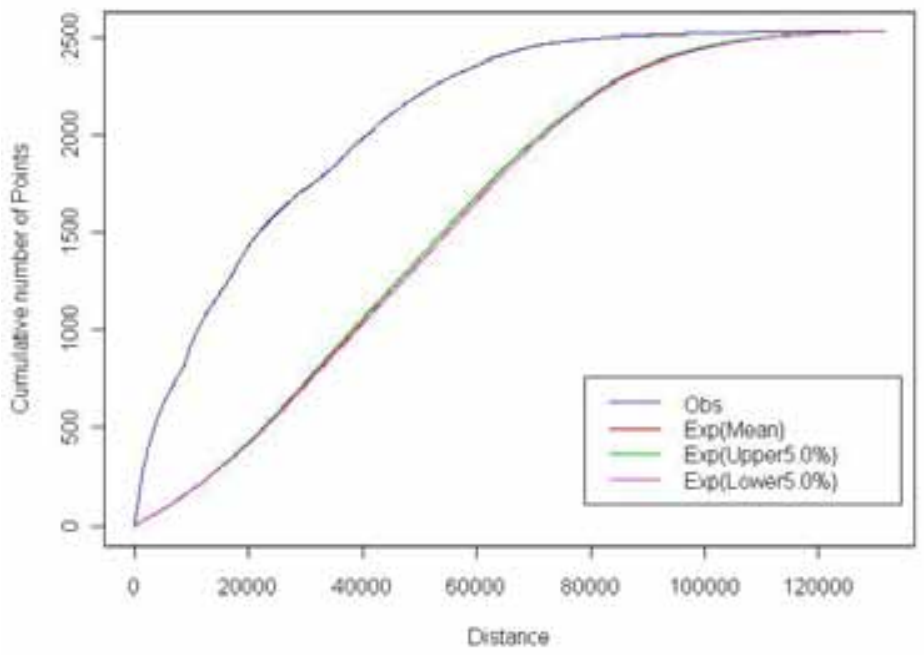

Fig. 6.

The Result of Network K- Function Analysis 


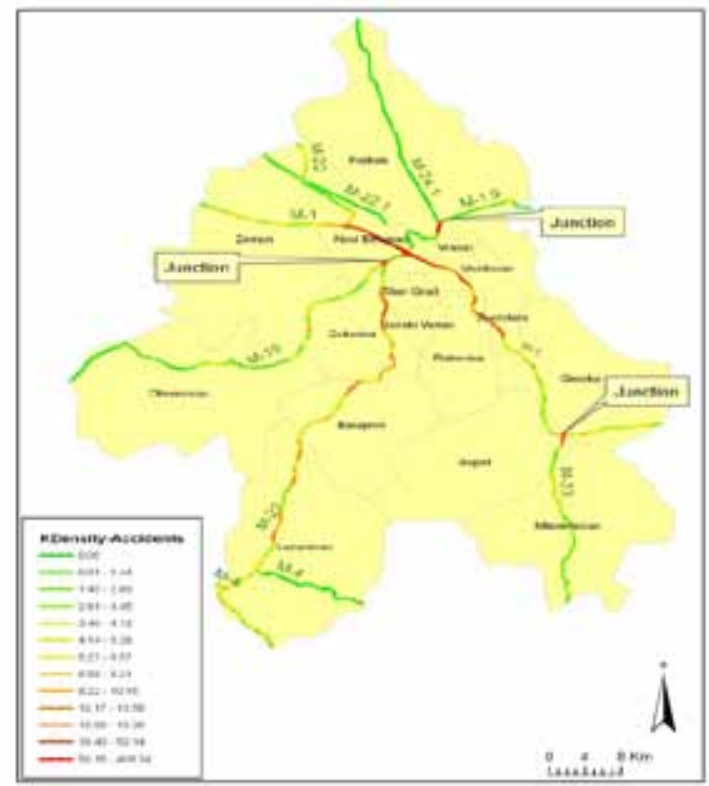

Fig. 7.

Network Kernel Density Estimation with a Radius of $1 \mathrm{~km}$ and Cell Size of $500 \mathrm{~m}$

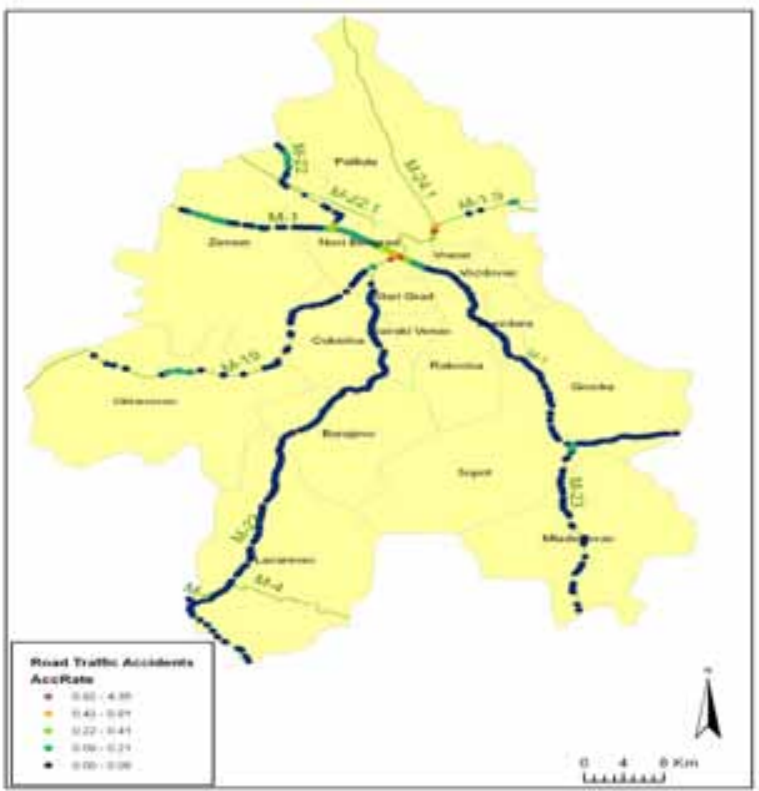

Fig. 8 .

Distribution of Accident Rates

jitte 10 
Even though these sections are part of a major road network, they lie in an urban area. Another indicator of the high traffic data is the fact that New Belgrade has been chosen as the most suitable location for business institutions over the last ten years.

Using Point Density in Spatial Analyst Tools with a bandwidth of $1 \mathrm{~km}$ and a cell size of $500 \mathrm{~m}$ showed that $\mathrm{M}-1$ and $\mathrm{M}-22$ were most likely to have a higher number of accidents (Fig. 5).

\subsubsection{Network K- Function}

By running the SANET tool (Okabe et al., 2006) and using the Network K- function, it was possible to see whether or not the accident locations were clustered or dispersed in a road network. Fig. 6 shows the result of applying the network K-function to the major road network of Belgrade with 1000 iterations and a class interval of $100 \mathrm{~m}$. The result revealed a statistically significant cluster pattern of road traffic accidents with respect to each other as the observed curve was seen by far to the left of the expected upper $5 \%$ curve.

\subsubsection{Network Kernel Density Estimation}

As the network $\mathrm{K}$ function suggested the presence of clusters in the given network, the next step was to find the sites of accidents. Fig. 7 illustrates the density points in the road network calculated by the Network Kernel method which gave a more accurate account of the distribution of events at the $\mathrm{road} / \mathrm{street} \mathrm{level} \mathrm{especially} \mathrm{on} \mathrm{a} \mathrm{micro-scale.}$ The Network Kernel method revealed that sections of M-1 (which pass through municipalities in New Belgrade, Vracar, Vozdovac and Zvezdara) and some sections of M-22 in the south were the most heavily congested with clusters.
The accident rates were also calculated (Fig. 8), which revealed that the accident rate on the magisterial roads in the congested areas of Novi Beograd and Zemun seems to be higher than in other parts of the City of Belgrade.

\subsubsection{Multiple Regression Analysis}

The multiple regression analysis revealed that the most significant variable that had the strongest impact was dMC3 (speed) followed by dRC1 (straight roads). Speed is often reported as one of the main factors (Elvik et al., 2004) in RTAs. The curved and saddle - dRC2 variable which is ranked as the $5^{\text {th }}$ in the model is less significant because this case study was done for major roads in a highly urbanized area (section 1.2 - curved roads affect accident rates more at a district level) and most of them are highways with less curves considering the geographical features of Serbia.

Special attention should be paid to the driver's behavior in the Balkans. In fact, it is not just the vehicle drivers but also the motorcyclists and pedestrians who take part in accidents. Due to the nominal fines and the scarce operation of police patrols, drivers and pedestrians tend to disregard the traffic regulations. The presence of cameras, radars, a good system of reporting the cases to the police, and a connection to the address system which can send fines to the living/working place of individuals have shown better results in developed countries.

The relevance of dRS3 - glazy roads is selfexplanatory, but it is in fact listed as less significant, because drivers are more careful and likely to reduce speed under severe road conditions owing to adverse weather or other environment factors. $\mathrm{dH} 2$ - variable shows that accidents happen more often during the period of 10-16. These are the 
working hours of public institutions (such as ministries, embassies etc.), rather than the rush hour. Business hours for institutions and private businesses are from 8-17 or 9-18 thus the rush hours are counted as part of either the Morning or the Afternoon period. Furthermore, the category of rush hour would be more significant if accidents in urban streets were considered rather than those on the major roads.

Based on Table 2 the following multiple linear regression model is produced with a statistically significant $F$ value of 19.538 $(\mathrm{p}<0.05)$ (Eq. (5)):

$\mathrm{Y}=-0.076+0.093 \mathrm{dMC} 3+0.066 \mathrm{dRC} 1+$ $0.028 \mathrm{dH} 2+0.045 \mathrm{dMC} 2-0.068 \mathrm{dRC} 2+$ 0.133 dSC1 -0.149 dRS3

The table of regression coefficients shows that $\mathrm{dRC} 2$ and $\mathrm{dRS} 3$ have a negative value which means that 1 . accident rates on a curved/ saddle road are 0.068 lower than at a level crossing (dRC4 - reference variable), and 2. accident rates on glazy roads -0.149 are lower than on snow-covered roads (dRS4 - reference variable). All other coefficients are positive, indicating that accident rates are higher than the reference variable.

\section{Conclusions}

Annual data collected by SEETO from 20032009 used in this study gives an overview of road safety figures in WB countries. The results of this paper show that it would take a long time for the developing countries to reach the RTA rates of high-income countries if they proceeded with the same steps. The small but visible decrease in road fatalities in 2009 demonstrates that these countries are working on reducing RTAs. The figures from EUROSTAT show that developing countries are the most affected. In the poorest countries within WB such as Albania, Kosovo and Macedonia, there is some increase in road accidents compared to the other countries of the region.

Table 2

Regression Coefficients

\begin{tabular}{|c|c|c|c|c|c|c|c|c|}
\hline \multirow{2}{*}{ Model } & \multicolumn{2}{|c|}{$\begin{array}{c}\text { Unstandardized } \\
\text { Coefficients }\end{array}$} & \multirow{2}{*}{$\begin{array}{c}\begin{array}{c}\text { Standard } \\
\text { Coeffi- } \\
\text { cients }\end{array} \\
\text { Beta }\end{array}$} & \multirow{2}{*}{$\mathbf{t}$} & \multirow{2}{*}{ Sig. } & \multicolumn{3}{|c|}{ Correlations } \\
\hline & B & $\begin{array}{l}\text { Std. } \\
\text { Error }\end{array}$ & & & & $\begin{array}{l}\text { Zero- } \\
\text { order }\end{array}$ & Partial & Part \\
\hline (Constant) & -0.076 & 0.068 & & -1.118 & 0.264 & & & \\
\hline dMC3 & 0.093 & 0.014 & 0.229 & 6.802 & 0.000 & 0.155 & 0.134 & 0.132 \\
\hline dRC1 & 0.066 & 0.017 & 0.091 & 3.887 & 0.000 & 0.135 & 0.077 & 0.075 \\
\hline dH2 & 0.028 & 0.008 & 0.068 & 3.502 & 0.000 & 0.072 & 0.070 & 0.068 \\
\hline dMC2 & 0.045 & 0.015 & 0.105 & 3.106 & 0.002 & -0.097 & 0.062 & 0.060 \\
\hline dRC2 & -0.068 & 0.030 & -0.053 & -2.276 & 0.023 & -0.104 & -0.045 & -0.044 \\
\hline dSC1 & 0.133 & 0.065 & 0.040 & 2.043 & 0.041 & 0.044 & 0.041 & 0.040 \\
\hline dRS3 & -0.149 & 0.074 & -0.039 & -2.014 & 0.044 & -0.042 & -0.040 & -0.039 \\
\hline
\end{tabular}


The Network K- function and the Network Kernel density methods were applied to the smaller-scale data of the City of Belgrade. They first determined the presence of clusters and then the location of these clusters. This could encourage further research for the purpose of determining the cause of accidents.

It turned out that the most exposed sections were found on the M-1 highway, especially among the sections that go through the municipality of New Belgrade. Even though they form part of a major road, these sections pass through an urban area where heavy traffic congestion is shown in the AADT map. Moreover, M-1 connects the city of Belgrade with other cities in the surrounding area, which means that vehicles use these section roads as main routes for entering and reaching the desirable destination in the city, which is relevant to the explanation of the $\mathrm{dH} 2$ variable impact.

From the MLR method results it can be concluded that the dMC3 - speed, dRC1 - straight roads and $\mathrm{dH} 2$ - time of the day predictors have stronger effect on accident rates than $\mathrm{dMC} 2, \mathrm{dRC} 2, \mathrm{dSC} 1$ and $\mathrm{dRS} 3$ did. Driving at a high speed - dMC3 on a straight road - $\mathrm{dRC} 1$ is more likely to cause an accident than driving at a low speed. The probability of an accident is even higher if the time factor is added, especially the time interval (10-16) - $\mathrm{dH} 2$ variable time, which further explains an increase in accident rates. Also, speed and disregard for the rules were the two most significant causes that affected accident rates in this case study. Driving on a straight asphalted road can incite the driver to increase the speed above the limit, which can result in an undesirable event.

Future research might further explore the methodology of finding the clusters of RTAs over space and time. The specific spatial and temporal patterns exhibited by these RTA clusters would be of significant interest to the public authorities. Once this methodology is completed, it could be used as a framework for examining traffic accident distribution for the entire country, and it can be used as an example for other countries in WB.

At the stage of analyzing data by GIS, a sustainable database system that stores the locations of accidents should be established. The actual data analyzed in this study, the location of which was found by linear referencing, is limited in accuracy. GPS devices should be used and integrated with the database, which enables the identification of the exact location of the event and the database update. The system should provide access to people in charge of local road safety, who can help and decrease the number of RTAs.

Finally, there is an advantage if countries are using or participating in a regional system like the European International Road Traffic and Accident Database (IRTAD) or the AsiaPacific Road Accident Database (APRAD) run by the UN-ESCAP. A regional system for WB still does not exist, as it should be first set up at the national level, and this study will hopefully contribute positively to the debate on establishing such a data system.

\section{Acknowledgement}

The authors would like to express their gratitude to Criminology Police Academy who provided them with Road Traffic Accidents data for 2007 in Serbia, and South East Europe Transport Observatory (SEETO) who provided them with annual statistical data of road safety and polygon features of the Western Balkan countries. Authors are also 
grateful to the Republic Geodetic Authority of Serbia for providing them with features of a major road network of Serbia.

\section{References}

Aeron-Thomas, A. 2000. Under-reporting of road traffic casualties in low income countries. TRL Report PR/ INT/199/00. TRL Ltd., Crowthorne: CSIS Discussion.

CARE database - reports and graphics. Available from Internet: <http://ec.europa.eu/transport/road_safety/ specialist/statistics/index_en.htm $>$.

Council Decision 93/704/EC. 1993. Oj No L329. 63-65.

Dai, D. 2012. Identifying clusters and risk factors of injuries in pedestrian-vehicle crashes in a GIS environment, Journal of Transport Geography. DOI: http://dx.doi.org/10.1016/j. jtrangeo.2012.02.005, 24(2012): 206-214.

Elvik, R.; Christensen, P.; Amundsen, A. 2004. Speed and road accidents: an evaluation of the Power Model. TOI report 740. Oslo: The Institute of Transport Economics.

European Transport Safety Council - Estimating Crash Cost. Available from Internet: <http://www. grsproadsafety.org/themes/default/pdfs/Estimating\%20 crash\%20 costs.pdf $>$.

European Transport Safety Council - Social and economic consequences of road traffic injury. Available from Internet: <http://www.etsc.eu/documents/Social\%20and\%20 economic\%20consequences\%20of\%20road\%20traffic\%20 injury\%20in\%20Europe.pdf $>$.
Jacobs, G.; Aeron-Thomas, A.; Astrop, A. 2000. Estimating global road fatalities. TLR Report 445, Transport Research Laboratory.

Okabe, A.; Yomono, H.; Kitamura, M. 1995. Statistical Analysis of the Distribution of Points on a Network, Geographical Analysis. DOI: http://dx.doi. org/10.1111/j.1538-4632.1995.tb00341.x, 27(2): 152-175.

Okabe, A.; Okunuki, K.; Shiode, S. 2006. SANET: A toolbox for spatial analysis on a network, Geographical Analysis, 38(1): 57-66.

Okabe, A.; Satoh, T.; Sugihara, K. 2009. A kernel density estimation method for networks, its computational method and a GIS-based tool, International Journal of Geographical Information Science. DOI: http://dx.doi. org/10.1080/13658810802475491, 23(1): 7-32.

South East Europe Transport Observatory - MAP. 2011. Available from Internet: <http://www.seetoint.org/index. php?option $=$ com_content $\&$ view $=$ article $\&$ id $=372 \&$ Ite $\operatorname{mid}=104>$.

Yamada, I.; Thill, J.C. 2002. Empirical Comparisons of Planar and Network K-functions in Traffic Accident Analysis. In Transportation Research Board $82^{\text {nd }}$ Annual Meeting, Washington, D.C.

Global Status Report on Road Safety 2009 - World Health Organization. Available from Internet: <http://www.who. int/violence_injury_prevention/road_safety_status/ key_data/kd_ai.pdf $>$. 


\section{INTEGRISANJE GIS-a I PROSTORNO ANALITIČKIH TEHNIKA U ANALIZI SAOBRAĆAJNIH NEZGODA U SRBIJI}

\section{Liljana Çela, Shino Shiode, Krsto Lipovac}

Sažetak: Pitanje bezbednosti saobraćaja privlači veliku pažnju lokalnih organa vlasti u kontekstu smanjivanja broja nezgoda na putevima. Šire razmatranje ovog problema predstavlja prikaz situacije u zemljama članicama Evropske Unije, a zatim i u zapadnobalkanskim državama: Albaniji, Bosni i Hercegovini, Hrvatskoj, Makedoniji i Srbiji. Alat SANET u ArcGIS Desktop-u omogućava primenu mrežne K-funkcije i metoda mrežne gustine jezgra. Za razliku od tzv. planarnih metoda, mrežne metode su nepristrasne jer se koriste u slučaju kada se nezgode dogode na tzv. mrežnom putu. Mrežna K-funkcija treba da pokaže postoje li grupisanja, a metod mrežne gustine jezgra se primenjuje za utvrđivanje lokacija grupisanja. Da bi se došlo do najznačajnijih varijabli koje su u vezi sa uslovima na putu, vremenom i glavnim razlogom koji utiče na visoku stopu nezgoda primenjuje se metoda višestruke linearne regresione analize. Ovo istraživanje je sprovedeno za grad Beograd sa predlogom za daljim istraživanjima. Rezultati ovog istraživanja mogu da posluže za definisanje najznačajnijeg uzroka saobraćajnih nezgoda u posmatranom području i primena se može proširiti i u drugim zemljama regiona.

Ključne reči: GIS, saobraćajne nezgode, analiza mreže. 